\title{
建築物の言語描写における光の多義性 POLYSEMY OF LIGHT IN TEXT DESCRIPTION OF BUILDINGS
}

\author{
北川啓介*, 内藤拓也**, 寺田享平*** \\ Keisuke KITAGAWA, Takuya NAITO and Kyohei TERADA
}

\begin{abstract}
When we describe a certain phenomenon, we express our phrases composed of appropriate words which are chosen from varieties of languages. Since the process where we create meaning of words is based on our own mental activity, one word would have numerous meanings. Thus, polysemy occurs in languages. For these backgrounds, there is a word: light, which has been described for various meanings of words in terms of linguistic activity by architects. Meanings from light are organized by their own several recognitions to space. In this research we consider polysemy of light as a description of words in statements by architects.
\end{abstract}

Keywords : Polysemy, Light, Text Description, Adjectival Term, Verbal Term, Recognition Model 多義性，光，言語描写，形容句，作用句，認識モデル

\section{1.はじめに}

人間がある事象について言葉を用いて描写する際, 複数ある言葉 の選択肢の中から取捨選択を行い，文章を構成する。また，同じ言 葉を用いたとしても，その言葉に込められる意味は一様なものとは 限らない。これは, 人間の言葉の意味形成を行う過程が自身の精神 的活動や過去の体験や経験に基づくためであり，これにより一つの 言葉に対して複数の意味が形成され，言語の多義性が生まれる。こ れは，建築家が実空間を言葉により描写する際にも同様のことがい える。建築家の言説は，建築家の創作論や空間の認知・解釈といっ た精神的活動，または過去の経験や体験などを培ってきた自身の思 想活動を基に語られている。建築家の言説で用いられる言葉の意味 は，建築家の空間に対する独自の解釈により意味形成が行われ，建 築領域の中で独自の多義性が生まれるといえる。

これらを背景として，現代まで建築領域の中で多様な言語描写を されてきた言葉に光がある。光は, これまで建築領域の中で初源的 な要素として扱われ，建築空間に対寸る様々な言語描写の中で常に 光が係わりをもちながら述べられてきたと言っても過言ではない。 例えば，古代・中世の建築においては光を内部空間に取り入れる際 に，太陽に関する自然光を主として，反射や拡散などといった現象 を考慮し, 空間の明るさを生み出すため, 建築物の形態や開口に対
しての操作により光を扱ってきた。近代においては, 電球の発明に より, 人工的な光として新たな明るさが生み出され, ガラスの大量 生産や構造の自由化は設計において形態や開口に自由度を与えるな ど，多様な手法により光が扱われた。現代においては，それまでの 歴史の中で様々に解釈された光に対し, 光自体の意味を求め, 照明 器具やガラスなどの技術進歩と相まって, より抽象的な概念を与え られた光や, より具体的な環境的性能として捉えられる光など様々 な建築家による光の解釈が生まれている。このような光による現象 が起こるため, 建築家の創作論, 空間の認知・解釈において, 建築 家独自の言語描写が発達してきたと考えられる。

このように建築家は各々の時代において常に光について思考し, 建築空間を創作し，建築空間に反映させてきたといえる。そして， 建築家が実空間を自身の言葉によって表現する際に, 光に対して多 様な言語描写をしてきた。つまり, 光は建築家による多様な解釈の 基に, 意味形成され, 建築領域の中で独自の多義性が見出されてき たといえる。これら建築家の, 光に対する様々な解釈のもとに生ま れた光の多義性を導出することは, 建築家が思考し, 創作してきた 建築空間を読み解き, 評価する上でも重要な指標になると考える。

そこで本稿では, 建築物の言語描写における光の多義性を明らか にすることを目的とする。

\footnotetext{
* 名古屋工業大学大学院つくり領域 准教授 $\cdot$ 博士 (工学) Assoc. Prof., Tsukuri College, Graduate School of Engineering, Nagoya Institute of Technology, Dr. Eng.

** ジェイアール東海コンサルタンッ侏) 修士(工学)

*** 積水八ウス侏) 修士(工学)

JR Central Consultants Company, M. Eng.

Sekisui House, Ltd., M. Eng.
} 


\section{2. 既往の研究}

これまで，建築家の言説における修辞に着目した研究としては， 成瀬徳行による多彩な内容の言説が如何にして生成されるかを明ら かにしようとした, レトリックに関する一連の研究 ${ }^{123)}$ が挙げられ る。これらの研究は, 建築家の言説を対象として, これらの構造を 建築家の語り口・文章表現といった視点に加え，その表現自体の示 す建築家の自作品に対する認識や読み手に与える印象として考察を 進めることで, これらの変換操作が建築家の言説の内部構造として 存在し, 多彩な言説の生成現象であると位置づけている。本稿は, 建築家の言説を扱い, 言語描写における修飾表現に着目し, 分析を 行う点については既往論文と同じ立場を取っている。すなわち，建 築家の表現技法やレトリックの手法といった言説内の内部構造を背 景に，建築領域の中で光が語られることで帯びてきた意味の多様さ を探ることを目的とする。

次に，建築家の言説における対となる二つの言葉に着目し，建築 家の解釈を明らかにする研究としては, 塩崎太伸らによる言説が単 純な二項対立による二元論としてではなく, 多元的状況を対照性に よって再構成するものであると捉え，文脈における対概念の設定方 法及び対概念の差異の特徴や対照関係を明らかにしている研究 ${ }^{4)}$, 山 内一晃らによる設計者自身が表現する言葉を研究対象とし，抽象的・ 概念的な内容を表現する「概念語」と，具体的・実体的な内容を表 現する「形態語」に分類し，これらの言葉の果たす役割と相互の関 係を明らかにしている研究 ${ }^{5)}$ が挙げられる。本稿では, 形容句・作 用句という修飾表現に対する二つの概念を導入し，分析を進めてお り，光という言葉に対して，これら二つの概念との相互の関係を論 考するという点で後者の立場をとるものである。

また，光の認識において，光を定量的に表現する手法を提案した 研究としては，小泉隆らによる空間内で際立つ自然光が主要素であ る空間のまとまりや方向性に着目し，光を主要因とする空間構造に 係わるイメージとしてのまとまりと方向性について類型化を行った 研究 ${ }^{6}$, 熊澤貴之らによる光環境の質の高さの判断基準が各個人の評 価によって大きく異なることに着目し，個人が体験的に室内光環境 の認識と評価にどのように影響を及ぼすかを明らかにした研究 7), そ して，吉澤望らによる建築家の言説において，視覚的に知覚可能な 現象としての光に着目し，個人的な経験や知識を受けにくい視覚心 理学の知見を基に定量的に光を捉えることで, 現象としての光の表 出の工学的条件を明らかにした研究 ${ }^{8)}$ が挙げられる。本稿における 光の分析と認識は, 光を実空間における物理現象の光として定量的 に捉えているわけではなく，あくまで言語描写の中で扱われる光の 解釈として捉えて分析を行っている。よって, 光における認識の点 についても，上記の 3 つの研究とは異なる立場をとるものであると 考える。

以上より，本稿では，建築家が建築領域の中で光という語をどの ように扱い, 多義性が生み出されてきたのかを明らかにするため, まず，建築家の言説を扱い，形容句と作用句という二つの言葉から， 光の一側面の意味付けのされ方を語句同士の客観的な相関として分 析を行っている。そして，その結果を背景とし，建築空間における 光の認識のされ方をモデル化することで，空間描写の中で帯びる光 の意味の多義性を追求するものである。

\section{3. 研究対象}

本稿では, 建築領域における言語の多義性を考察する上で, 研究 対象を実際の建築空間の言語描写がされている言説とした。

これを踏まえた上で，時代に対して文献の量に偏りがなく，建築 家の言説として十分な資料を得ることができる点を考慮して，現代 まで継続的に建築作品及びその解説文を掲載している建築専門誌で ある『新建築』9) を研究資料とする。そして，1945 年から 2008 年ま でに掲載された建築家自身の作品に対する解説文の中で，建築空間 と係わる光についての記述を研究対象とする（表 1 )。

なお，1945 から 1949 年までの『新建築』では，作品に対する解説 文が極端に少なく, また執筆者の文責が不明確であったため研究資 料として十分な研究対象が得られず，研究資料から除外した。

表 1 年別研究対象数

\begin{tabular}{|c|c|c|c|}
\hline 年 & 対象数 & 年 & 対象数 \\
\hline $1950 \sim 1954$ & 47 & $1980 \sim 1984$ & 126 \\
\hline $1955 \sim 1959$ & 40 & $1985 \sim 1989$ & 133 \\
\hline $1960 \sim 1964$ & 40 & $1990 \sim 1994$ & 148 \\
\hline $1965 \sim 1969$ & 51 & $1995 \sim 1999$ & 179 \\
\hline $1970 \sim 1974$ & 77 & $2000 \sim 2004$ & 188 \\
\hline $1975 \sim 1979$ & 120 & $2005 \sim 2008$ & 147 \\
\hline \multicolumn{2}{|r|}{} & 計 & 1296 \\
\cline { 2 - 4 }
\end{tabular}

\section{4. 研究の流れ}

以下に研究の流れを段階的に示寸。

1）『新建築』に掲載された建築家の作品に対寸る解説文の中で建 築空間と係わる光についての記述を研究対象として選出する（図 1 )。建築空間と係わる光についての記述とは，言説の中で語られ る建築空間に生じる光の物理的現象や概念的効果を指す。

\begin{tabular}{|c|c|c|c|}
\hline 『新建築』1972年 2 月号 & & 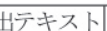 & 分類 \\
\hline 粟辻邸 / 東孝光建築研究所 & & & \\
\hline このの家ほど㢄と夜の状況が変化するのも珍しいだろう。 & क & 光 & 【光】 \\
\hline 昼は最高に素晴らしい，広い空，高い天井，吹抜のガ & 䫤 & & \\
\hline ラス天井から豊し込む光は白い壁に映えて压倒的，何 & & & \\
\hline も演出するものはいらない, あっけらかんとした空間 & 容 & 圧倒的 & [苛烈] \\
\hline そのものだけでいい. 戸外と室内の差を取り去るくら & & & \\
\hline いさわやかで明るく，そして飛び回る子供の世界. 設 & & & \\
\hline $\begin{array}{l}\text { 計依頼の時「体育館みたい殺風景でも結構です」といっ } \\
\text { たことを覚えているがまさしくそんな気がする. }\end{array}$ & 用 & 差し込む & [侵入] \\
\hline
\end{tabular}

図 1 光の種類・形容句・作用句の抽出例

2）建築空間と係わる光についての記述をキーコンテクスト注1)とし て抽出し, 建築空間で捉えられる光を光の種類として抽出し, 性 質・状態を表現する形容的な修飾句を形容句注2)，動作・作用を表 現する作用的な修飾句を作用句注 3) として抽出し，分類する。形容 句・作用句は, 光の種類と組み合わさることで光の一側面として の意味を決定づける，研究対象内で描写される要素である。

3）光の種類と形容句，作用句から，それぞれコレスポンデンス分 析注4) を行い, 分類同士の相関を整理する。

4）建築空間における構成部材や素材などの空間要素と光の係わり 方を読み取り，建築空間においてどのように光が捉えられている のかを抽出し, 分類した後, 光の認識モデルとして導出する。

5） 3），4）を考慮し，建築物の言語描写における光の多義性につい て考察し, 結論を導く。 


\section{5. 光の分類方法}

研究対象から，建築空間と係わる光についての記述をキーコンテ クストとして抽出し，抽出したキーコンテクストから建築空間で捉 えられる光, 明るさ, 日照, 輝度などといった光に関連した語句を 取り出し, その語句自体が意味する内容を判断し, 光の種類を分類 寸る (表 2 )。これにより，日本語の表記における漢字表現・平仮名 表現・送り仮名の差異を解消し, 空間内に描写された光の種類を考 察することができる。

表 2 光の種類

\begin{tabular}{|c|c|c|c|c|c|}
\hline 分類 & 記述例 & 分類 & 記述例 & 分類 & 記述例 \\
\hline 【光】 & 光/微光/昼光 & 【明度】 & 明度 & (光影) & 光と影 \\
\hline 自然光 & 自然光/天空光 & (照度 & 照度 & もれび & 木漏れ日 \\
\hline 陽・日” & 太陽/日射し & 【光束】 & 光束/光の束 & 【ひだまり & 日だまり \\
\hline 【外光 & 外光/外部光 & 【輝き】 & 輝き & 光沢 & 光沢/光沢感 \\
\hline 【日照 & 日照/日射 & (光明 & 光明 & 色光 & 光の色 \\
\hline 照明 & 照明/蛍光灯 & (光線】 & 光線 & (光彩 & 光彩 \\
\hline あかり & 明かり/灯 & (閃光) & 閃光 & 光環境) & 光環境 \\
\hline (明るさ) & 明るさ & 【光芒】 & 光芒/光のライン & 【採光】 & 採光 \\
\hline 【輝度】 & 輝度 & 【矓輝】 & 矓輝 & 【特殊光 & 光の饗宴 \\
\hline
\end{tabular}

\section{6. 形容句と光の種類のコレスポンデンス分析}

形容句は性質・状態を表現する形容的な修飾句であり，光の種類 と組み合わさることで言語描写内での光の一側面を意味づける要素 である。抽出した形容句を，感覚や感情をあらわす句，状況や物理 的側面をあらわす句などに着目し，分類する（表 3 ）。

表 3 形容句の分類

\begin{tabular}{|c|c|c|c|c|c|}
\hline 分類 & 記述例 & 分類 & 記述例 & 分類 & 記述例 \\
\hline [時間] & 夕刻の/午前の & [大小] & 巨大な/小さな & [均質] & 均質な/一定の \\
\hline [季節] & 夏季の/冬の/冬至の & [明暗] & 明るい/暗めの & [適切] & 適切な/適度な \\
\hline [瞬間] & つかの間の/刻々 & [濃淡] & 濃い/淡い/濃淡 & [快適] & 快適な/心地よに \\
\hline 場所性 & 南国の/沖縄の & [鋭鈍] & 鋭い/鈍い & [爽快] & 爽やかな \\
\hline [方位] & 西の/東の/東西の & [硬軟] & 柔らかい/硬い & [奇怪] & 怪しい/異様な \\
\hline [万向] & 水平/垂直性 & 重量感 & 軽い/重い & 〔明瞭〕 & 澄んだ/明瞭さ \\
\hline [形状] & 半円の/三日月状の & [温冷感 & 暖かい/涼しい & [独特] & 特殊/独自の \\
\hline [線状] & 一条の/一筋の & \multirow{2}{*}{ 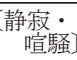 } & \multirow{2}{*}{$\begin{array}{c}\text { 静かな/ } \\
\text { 騒がしい }\end{array}$} & [繊細] & 精密な \\
\hline [本数] & 何本もの/2 本の & & & [愉快] & 面白い/楽しい \\
\hline [色] & 赤い/濃青の/七色の & [美醜] & 美しい/見事な & [直接] & 直接の/直射 \\
\hline [素材] & 金属的な/鉱物的な & [良否] & 良好な/よい & [間接] & 間接的な/間接に \\
\hline [透明] & 透明な/クリアな & \multirow{2}{*}{ 客定: } & \multirow{2}{*}{$\begin{array}{c}\text { 安定した/ } \\
\text { 不安定な }\end{array}$} & [有効] & 有効な/効果的な \\
\hline [輝煌] & 矓しい/まばゆい & & & [基礎] & 基本とされる \\
\hline [苛烈] & 厳しい/烈しい & [新旧] & 新たな/最新の & 幻想的 & 幻想的な \\
\hline [安穏] & 優しい/穏やかな & [豊富] & 豊かな/潤沢な & 抽象的 & 抽象的な \\
\hline 〔強弱〕 & 強い/弱い/強弱 & 〔充足] & 十分な/充分な & [情景] & おしやべりの \\
\hline [多少] & わずかな/多くの & [多様] & 多様な & & \\
\hline & & & & & \\
\hline
\end{tabular}

次に, 形容句と光の種類を抽出した結果，組み合わせ総数として 延べ 2014 組が得られ，コレスポンデンス分析を行い，分類の相関を 整理した（図 2 )。

そして, 分布図をゾーニングにより解釈した結果, 形容句と光の 種類の組み合わせは，時と場による光の限定，室環境に対する明る さの性能，感性により捉えられる光自体の性質の 3 つに整理できた。

〔方位〕，〔季節〕は，【陽・日】と強い相関を示し，主に太陽に 関する光の種類と組合わさる。「冬の」注 5), 「夏季の」注 6) や「北側 の」注7) などの描写を用いることで，光が太陽高度の影響を受け変化 する中で，建築家が特定の光の条件を意識していることが読み取れ る。また，〔場所性〕も，【陽・日】と比較的強い相関を示し，「北国 の光」注 8) などの描写により，地域特有の光をあらわしている。同様 に，〔時間〕も，【光】【陽・日】，【日照】と相関を示し，「夕刻の 光」注9)などの描写により，その光が特定の時間に限定的に現れる光

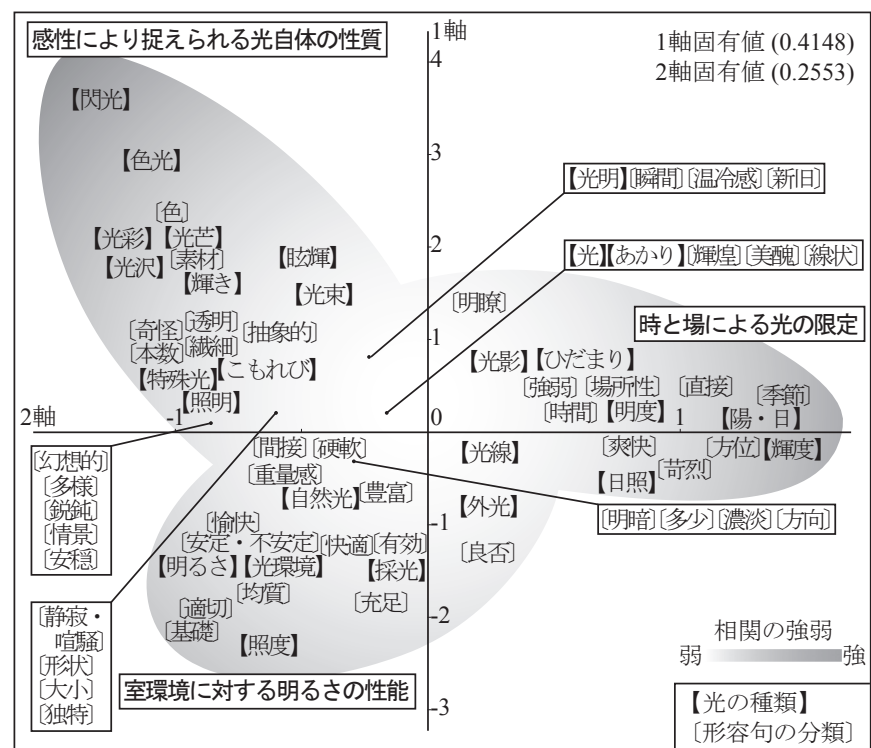

図 2 形容句と光の種類のコレスポンデンス分析散布図

であることが示されている。これらの描写は，光の気候的側面を強 めると同時に，建築物の敷地条件としての気候環境を表現している といえ，特に，【光】と組み合わさる場合は，太陽からの光であるこ とを隠喻的に表現している。太陽の変化の中で建築家が特定の光の 条件を意識していることが読み取れ, これらの形容句は, 時刻や方 位，場所性による光の限定を表現しているといえる。

【均質】，【適切】は，【明るさ】，【光環境】、照度】、採光】と 強い相関を示し，主に空間の明るさに関する光と組み合わさる。

〔均質〕は，「均等な照度」注10) などの描写により，光を変化するも のと捉える中で光の状態を一定に保つと共に，光が空間全体に分布 する広がりをもつものであることを表現しており，〔適切〕は，「適 度な」注11) などの描写により，その光の建築空間に対する良否の判断 を示すことで，室環境や人の生活を成立させる光を表現している。 また，原点付近にプロットされ，組み合わせの頻度として目立った 特徴はないが，組み合わせの型として特徵的なものがみられた。〔豊 富】は，【外光】【採光】、【自然光】など主に外部環境としての光の 種類と組み合わさり，「ふんだんな自然光」注 12) などの描写により， 建築空間に取り入れられる光の量的な豊かさを表現している。対し て〔方向〕は，【あかり】【光】【採光】【陽・日】と相関を示す。 これは光の伝わる方向を特定しており，建築空間に十分な光を入れ る際には，「多方面からの」注13) などのあらゆる方向を意味付ける形 容句，導入部分で光を調節する際には「水平からの」注14) などの一定 の方向を意味付ける形容句が光と組み合わさる傾向にあった。これ らの形容句は，主に室環境に対する明るさの性能を表現しており， 建築空間に対する良好な光環境の獲得が基本的な光の捉え方として 現われたものといえる。

〔色〕は, 【色光】,【光沢】と強い相関を示し，また，【光彩】【光 芒】、【閃光】【照明】とも組み合わさる。「4 色のアッパーライト は」注 15) といった照明の色によって空間の演出を表現するもの，「ピ ンクの光線で埋まったチューブの中」注16) といった空間の色彩を光に 例えて表現するもの，「白い太陽光」注 17) といった不可視な光の色に より空間に導かれる太陽光のイメージをより象徵的に表現する描写 がみられた。対して，〔素材〕は，【光沢】，【輝き】と強い相関を示 
し,【光】,【陽・日】,【光線】,【光影】、【あかり】,【光彩】とも組み 合わさる。「金属的な」注18) などの言葉を用いることで，ものや素材 の表面に固有にあらわれる光を捉えており，例えば，木材の表面に あらわれる光であっても,「いぶし銀のような」注19) といった全く違 う素材の描写によって, その素材が表出する固有の光を表現してい るものが多い。建築空間に多用される一般的な素材であっても,「ダ イヤモンドのごとく」注20) などの描写を用いることで, 固有の光の存 在を描写し, 建築空間の中で象徴的な存在として表現している。〔透 明】は, 【光】、【特殊光】と相関を示寸。本来, 視覚により捉えるこ とができない透明な色の意味を光に与えることで, 空間的な光の透 き通るといら性質から，より空間の澄みきった印象を意識的に強調 している。同様に, 〔硬軟〕, 〔静寂・喧騒〕, 〔温冷感〕は, 【光】, 【自然光】【日だまり】と相関を示す。〔硬軟】は，本来視覚により 捉えられる光を「柔らかい自然光」注21) などの描写により, 触覚とい う他の五感になぞらえて表現することで, 光の描写と同時に空間の 䨌囲気を効果的に表現しており，〔静寂・喧騒〕や〔温冷感〕のよう に, 「静かな日溜り」注22), 「冷たい光芒」注23) など, 聴覚, 知覚にな ぞらえた表現もみられた。これらの形容句は, 空間をより象徴的に 表現するために光自体のもつ特徴を意識的に強調しており，時には 誇張的な描写を用いることで感性により捉えられる光自体の性質を 表現しているといえる。

\section{7. 作用句と光の種類のコレスポンデンス分析}

作用句は動作・作用を表現する作用的な修飾句であり，光の種類 と組み合わさることで言語描写内での光の一側面を意味づける要素 である。抽出した作用句を, 移動や発光など光の能動的側面をあら わす句, 管理や操作など光の受動的側面をあらわす句などに着目し, 分類する (表 4 )。

次に, 作用句と光の種類を抽出した結果, 組み合わせ総数として 延べ 1904 組が得られ, コレスポンデンス分析を行い, 分類の相関を 整理した（図 3 )。

そして, 分布図をゾーニングにより解釈した結果, 作用句と光の 種類の組み合わせは, 特殊な光の存在・経験, 動きを生じる光, 室 環境としての明るさの獲得の 3 つに整理できた。

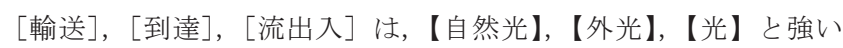
相関を示す。[輸送］は，「光を送り込む」注24)などの描写により， 光が運搬されるものとして捉えられ, 建築部位や素材が光を室空間 に運ぶように表現される。また, この作用句により, 建築部位や素 材は主体的に捉えられ, 光に対して能動的に作用を起こすものとし て表現される。[流出入]は, 「光がこぼれ出る」注25)などの描写に より, 光に水の動きの意味を付加することで, 光が建築空間を照ら 寸様子を印象的に表現しており, 同様に, 水の性質を表現するもの としては，[浸透］，[被浴］の「夕日が館内を染め」注 26)，「外壁が日 を浴びる」注27)などの描写もみられた。[包囲］は, 【光】と強い相 関を示す。「包み込む」注 28) などの描写により, 光が空間を覆って中 に入れるという光の能動的な動作が表現される。光が膜のような面 として捉えられているため, 特定の光源をもたない空間の明るさと しての光と組み合わさりやすい。また，【自然光】のように主に外部 環境や太陽に関する光の種類とも組み合わさり, 建築空間に光を取 り入れる際は, 人為的な光の調整をせず, 出来る限り自然界に存在
表 4 作用句の分類

\begin{tabular}{|c|c|c|c|c|c|}
\hline 分類 & 記述例 & 分類 & 記述例 & 分類 & 記述例 \\
\hline [生成 & Eられる/生じる & 侵入] & 射し込む & [獲得］ & 得られる/確保され \\
\hline [発光 & 灯る/輝く/点灯する & 流出入 & 注ぐ/こぼれる & [維持 $]$ & 保つ/保持される \\
\hline 照射 & 照らす/照射する & 落下] & 落ちる & [増強 $]$ & 増幅する/増す \\
\hline 放射 & 放つ/放出寸る & 移動] & 通過する & {$[$ [緩和 $]$} & 和らげられる/弱ま \\
\hline 投射 & 投射する/投げかける & 輸送] & 送り込まれる & [変化 $]$ & 変化する/移ろら \\
\hline [反射 & 反射する/照り返す & 到達] & 到達する/届く & [ 調整] & 制御される \\
\hline 拡散 & 拡散する/発散する & 浮動 & 漂う/浮遊寸る & 加熱梠 & 暖める/温める \\
\hline 透過 & 透過する/透す & 摇動 & 摇らめく & 演出」 & 演出される \\
\hline 浸透 & 浸透する/染み込む & 充満 & あふれる/満た & 表現］ & 表現される \\
\hline 被浴 & 浴びす/かけられる & 包囲] & 包む/囲う & [ [計画] & 計画される/図られ \\
\hline 遮断 & 遮断される/遮蔽 & 擋乱 & 乱れてる & [考慮] & 配慮される \\
\hline 拒否 & 拒否される & 埋没 & 埋められる/沈む & [必要] & 求められる \\
\hline [回避 & 避けられる/防がれる & 重合 & 交差する/重なる & [期待］ & 期待される/望まれる \\
\hline 尊入 & 入る/採り入れられる & 配置 & 並ぶ/配置される & [所有］ & 保有される/持たれ \\
\hline 誘導 & 導力氺る誘い込まれる & 付与] & 享受される & [利用] & 用いられる/利用され \\
\hline [経験] & 感じられる/満喫 & 擬人 & 歩屯/潜伏す & & \\
\hline
\end{tabular}

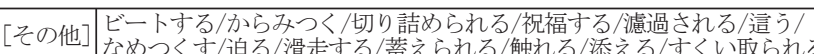

※[その他]の記述例は，共通の記述が少なく，分類することができなかったもの

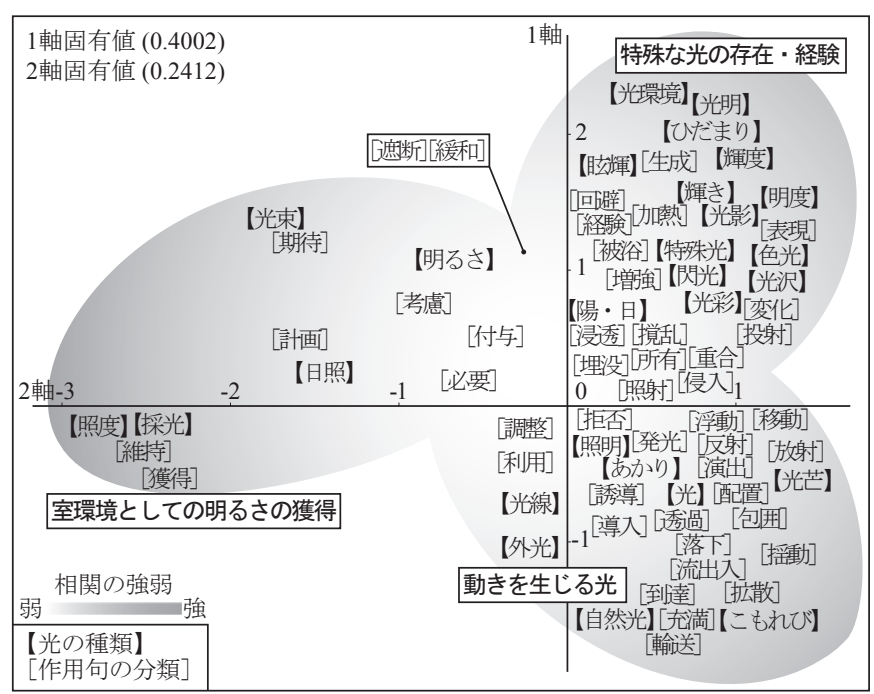

図 3 作用句と光の種類のコレスポンデンス分析散布図

する状態のまま取り入れようとする傾向が強いことが読み取れる。 また，原点付近にプロットされ，組み合わせの頻度として目立った 特徵はないが, 組み合わせの型として特徴的なものがみられた。[発 光，［照射］，［反射］は，【照明】，【光】【陽・日】と相関を示 す。特に [ 発光 ] は, 「輝く」注29) などの描写により, 光が光の物理 現象の中で捉えられることを示し，その上で，物体に照射すること で新たな輝きを生じさせているものや，【照明】などと組み合わさる ことで, 明滅可能な人工の光として捉えられているものがあらわれ た。これらの作用句は, 光に擬人的な意味を与え, 建築空間へ光が 照射され広がる様子を印象的に表現している。光を人やもののふる まいに置き換えることで，主体的な動きを生じる光を表現している といえる。注 59)

[生成はは【輝き】，【光影】，【ひだまり】【特殊光】と強い相関を 示す。「つくる」注30) などの描写により, 光が建築家により創作され るものとして捉えられることを示す。また,【ひだまり】のような照 射部の光や，「光の分布」注31) といった空間に広がる光など空間と係 わりの強い光が組み合わさりやすい。[表現] は,【光影】，【輝き】 と強い相関を示す。「表す」注32) などの描写により, 人為的につくら れる光が捉えられており, 建築家の設計手法としての建築物の構成 や素材の選択によって固有の生じる光を表現しているといえる。［経 
験】は【陽・日】,【特殊光】、【光影】、【輝き】、【ひだまり】,【光】 などと相関を示す。「体感する」注33) などの描写により, 光が人に知 覚を起こさせるものとして捉えられ建築空間の中で人が光を目にし たり, 感じ取ったりする様子が表現されていた。[被浴］は, 【光】, 【自然光】と相関を示す。「外壁が日を浴びる」注 34 などの描写によ り, 光に水のような性質の意味を付加寸る中で, ものや素材が光に 照らされる様子を水を被る様子に例えることで表現している。その ほとんどが【太陽光】と組み合わさることから，太陽からの強い光 が差し込む様子が，大量の水を被る様子を想起させるためにこのよ うな表現が用いられると考えられる。これらの作用句は,【ひだま り】、【輝き】、【光明】、【光影】などの特定された光の種類と組合わ さり, 開口や天井などの構成を人の経験としての光の様子と共に表 現することで, 建築空間の物理的構成から得られる空間の豊かさを 特殊な光の存在・経験として表現しているといえる。

[獲得 $]$, [維持］は,【照度】、【採光】、【日照】と強い相関を示 す。「明るさを保つ」注35) などの描写により，人為的に光の環境を維 持する様子が表現され, 良好な環境をつくり出すための条件や機能 の意味が光に付加されている。また，主に【照度】と組み合わさる ことからも, 室空間の性能としての光の環境を充足しょうとする意 識が読み取れる。[計画］は，【採光】【日照】と強い相関を示す。 「計画する」注36) などの描写により，人為的に光が作られることを表 現している。主に室空間の明るさの充足に関する描写の中で用いら れ，建築家の採光計画や照明計画の説明に伴い用いられていた。ま た，原点付近にプロットされ，組み合わせの頻度として目立った特 徵はないが，組み合わせの型として特徴的なものがみられた。［付 与，［必要］は,【光】,【陽・日】,【照明】などと相関を示す。「受 けさせる」注37) などの描写により，建築部位や素材が空間や人に対 して光を与えている様子が表現され，建築部位や素材などの物体が 擬人化され，光に作用寸ることをあらわしている。これらの作用句 は, 光に対する部位や素材の擬態化を含め, 人為的な光の操作に関 する描写に多く現れ，室環境としての明るさの獲得を表現している といえる。

\section{8. 光の認識モデル}

建築領域における光に関する言語描写には，前章で整理した光の 種類, 形容句, 作用句の組み合わせによる分析に加えて, 光が係わ る構成部材や室といった, 空間要素を表す語を抽出することができ る。これらの語と光の係わり方をモデル化することで，建築空間に 生じる光を，建築家がじのような光として捉えているのかを読み取 ることができる。建築家は，空間を操作する手法として，太陽など の光源を, 空やルーバーなどの建築物の構成部材を用いて空間に導 入し，またその光は空間を満たす明るさとなり，ものや素材の表面 に陰影を生じさせる。また, これらの一連の現象は, 光度や光束, 照度, 輝度といった光の物理現象としても捉えることができる。以 上の光に関する側面を建築家がどのように捉えているのかを読み取 る為に, 光源としての光, 空間から空間へ移動する光, 空間の明る さとしての光, ものや素材の表面の明るさとしての光の 4 種類に分 けて, キーコンテクストから空間要素を表寸語がそれら 4 種類の光 にどのように関わっているのか抽出した。これらにより, キーコン テクストから建築空間で捉えられる光の違いを光の認識モデルとし

\begin{tabular}{|c|c|c|}
\hline \multicolumn{2}{|c|}{ 認識モデル } & 光に係わる空間要素と役割 \\
\hline & 光源としての光 & 光 - 〈〈太陽光》: 光源 \\
\hline$\longrightarrow$ & $\begin{array}{l}\text { 空間から空間人 } \\
\text { 移動する光 }\end{array}$ & 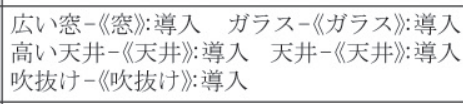 \\
\hline & $\begin{array}{l}\text { 空間の明るさ } \\
\text { としての光 }\end{array}$ & 空間 - 〈室》: 照射 \\
\hline 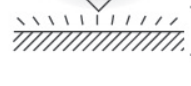 & $\begin{array}{l}\text { ものや素材の } \\
\text { 表面の明るさ } \\
\text { として光 }\end{array}$ & $\begin{array}{l}\text { 白-〈白》》: 反射 } \\
\text { 壁-〈壁》》: 反射 }\end{array}$ \\
\hline
\end{tabular}

新建筑 1972年2月号広い空, 高い天井, 吹抜けのガラス天井から射し込む光 「栗辻邸」は白い壁に映えて厈倒的，何も演出するものはいらな 東孝光建築研究所 い, あっけらかんとした空間そのものだけでいい.

図 4 認識モデルの抽出例

表 5 認識モデルの類型

\begin{tabular}{|c|c|c|c|c|c|}
\hline \multirow{4}{*}{\begin{tabular}{|l|} 
類型 \\
光源《 \\
\end{tabular}} & \multicolumn{2}{|r|}{ 光源 } & \multirow[t]{2}{*}{ 類型 } & \multicolumn{2}{|c|}{ ii 光源 - 移動 } \\
\hline & $\mathrm{i}-1$ もの光源 & i -2 太陽照射 & & ii -1 導入 & ii -2 遮断 \\
\hline & 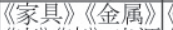 & 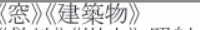 & 光搌 & $\langle$ 《陽光》: 光源 & 《太太陽光》: 光源 \\
\hline & 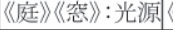 & 〈敷地》〈〈樹木〉》:照射 & 移動 & 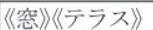 & $\mid\langle$ |ルーバー・庇》 \\
\hline 移動 & & & & 《樹木》》:導入" & 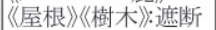 \\
\hline 空間 & & & 空間 & & \\
\hline 表面 & & & 表面 & & \\
\hline & iii 光源 - & 移動-空間 & 刑 & 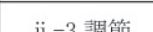 & \\
\hline & iii-1 導入 & iii-2 遮断 & 賛勂 & $11-3$ 响即 & \\
\hline 光源 & 《《太陽光》: 光源 & 《太陽光》: 光源 & 光源 & $\langle\langle$ 太陽光》: 光源 & \\
\hline 移動 & 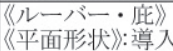 & $\begin{array}{l}\langle\langle\text { Uルバー・庇》 } \\
\langle\langle\text { }\end{array}$ & 移動 & 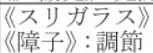 & \\
\hline \begin{tabular}{|l|l|} 
空間 \\
\end{tabular} & 《〈奥部》〈〈室》):照身 & 村テラス》〉:照射 & 空間 & & \\
\hline 表面 & & & 表面 & & \\
\hline 類型 & iv 光源 - 移 & 動-空間－表面 & 類型 & & 移動 \\
\hline 光源 & 《《太陽光》《照明啫 & 器具》》: 光源 & 光源 & & \\
\hline 移動 & 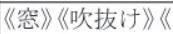 & ガラス》: 導入 & 移動 & 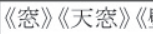 & 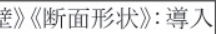 \\
\hline \begin{tabular}{|l|l|} 
空間 \\
\end{tabular} & 《室》: 照射 & & 空間 & & \\
\hline 表面 & 《壁》《〈白》: 反射 & & 表面 & & \\
\hline
\end{tabular}

\begin{tabular}{|c|c|c|c|c|}
\hline 類型 & vi移動 & 空間 & 類型 & vii 移動－空間－表面 \\
\hline 源 & IV 1 年分 & & |光源 & \\
\hline 移動 & 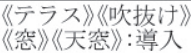 & 《ガラス》:遮断 & 移動 & 《空》〈〈天空》》: 導入 \\
\hline 空間 & $\langle\langle$ 室》: 照射 & 《室》;:照射 & 空間 & 《室》: 照射 \\
\hline 表面 & & & 表面 & 《白》〈壁》: 反射 \\
\hline
\end{tabular}

\begin{tabular}{|c|c|c|c|c|}
\hline 類型 & \multicolumn{2}{|c|}{ viii空間 } & \multirow{2}{*}{ 類型 } & ix 空間－表面 \\
\hline 光源 & & VIII-2剒强・惐哀 & & \\
\hline 移動 & & & 移動 & \\
\hline 空間 & 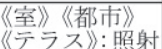 & $\begin{array}{l}\text { 《平面形状》》:増強 } \\
\langle 《 \text { 比 }\end{array}$ & 空間 & 《室》: 照射 \\
\hline 表面 & & & & 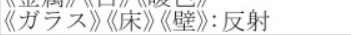 \\
\hline 類型 & \multicolumn{2}{|c|}{$\mathrm{x}$ 表面 } & 類型 & xi 概念 \\
\hline 光源 & \multirow{3}{*}{\multicolumn{2}{|c|}{$\mid$}} & 光源 & \multirow{4}{*}{ 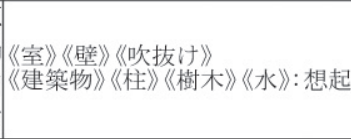 } \\
\hline 移動 & & & 移動 & \\
\hline 空間 & & & 空間 & \\
\hline 表面 & \multicolumn{2}{|c|}{ 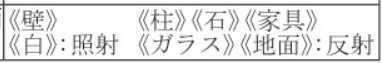 } & |宔间 & \\
\hline
\end{tabular}

て類型化した（図 4)。そして，前章までに整理した，光の種類，形 容句, 作用句の組み合わせによる分析に加えて, 光に係わる空間要 素となる語句を抽出し, それらの要素と認識モデルの組み合わせを 行った結果, 類型 $\mathrm{i} \sim x i$ に位置づけることができた（表 5 )。類型 $\mathrm{i}$ は，光源としての光のみが捉えられている認識モデルである。主に 太陽を光源として認識しているものがほとんどであるが，照明器具 の光を光源として捉えているもの，素材のもつ光沢として，ものや 素材の表面にあらわれる光を光源として捉えるものもみられた。実 際には光源ではないが，建築空間に対する特異点を示すような描写 においては，言語描写上では実際の光源は記述されず，それぞれの 空間要素が光源として捉えられている描写が多くみられた。類型 ii は，光源としての光が捉えられ，さらに，その光が空間から空間へ 
移動する光として捉えられている認識モデルである。ここで表現さ れる描写は, 光を導入する様子を表現する描写, 光を遮断する様子 を表現する描写，光を調節する様子を表現する描写がみられ，空間 要素と光の係わり方によって, 導入, 遮断, 調節といった, 光の描 写に違いがみられた。類型は, 類型 ii に加え, 新たな空間へと照 射されるまでの光が捉えられている認識モデルである。照射される 空間に対して光が肯定的・否定的に捉えられるかによって描写に違 いが生じている。また, 他の表現としては, 照明を光源として捉え, 室空間が照らされる様子を表現した描写, 建築物内の照明を光源と して捉え, 開口部などを通して, 光が敷地などの外部空間へと照射 される様子を表現した描写がみられた。類型 iv は, 類型 iii に加え, ものの表面の明るさとしての光が捉えられている認識モデルである。 光源として太陽が捉えられているものが大多数を占め, 太陽の光が 空や天空などの開口から導入され，また，建築物の素材に反射する 様子を表現する描写もみられ, 建築空間の構成と共に, それに伴う 豊かな内部環境が光の様子を表現した描写がみられた。類型 $\mathrm{v} は$ は, 空間から空間へ移動する光を捉えた認識モデルである。類型 ii に対 して, 光源が特定できない認識モデルであり, 主に建築物の外部空 間と内部空間の境界面に関する物理的構成の光に対する役割を表現 する描写であるといえる。類型 ii と同様に, 高空や天空の光を導入 する役割を表現する描写, ルーバー・庇の光を遮断, 緩和する役割 を表現する描写など, 建築物の配置や形状に対する光の獲得や遮断 を表現する描写がみられた。類型 vi は, 類型 $\mathrm{v}$ に室空間の描写が加 えられた認識モデルであり, 光源が特定されていないため, 描写が 室空間内で完結しているといえる。そのため, 開口部から導入され る光が室空間を照ら寸様子を表現している描写が多く, さらに, 室 空間に差し込む光を遮断, 緩和する描写がみられた。類型vii は, 類 型viに光がものや素材に反射する様子の描写が加えられた認識モデ ルであり, 光源が特定されていないため, 描写が室空間内で完結し ているといえ, 室空間の色に反射して空間が演出される様子をあら わしている描写がみられた。類型viiiは, 空間の明るさとしての光を 捉えた認識モデルである。内部空間に関する描写が大多数を占める なかで, 都市空間に生じる明るさに関する描写もみられた。さらに, 室空間や都市に生じる光自体の特徵を表現するための描写も多くみ られた。類型 $\mathrm{x}$ は, 空間の明るさとしての光を捉え, さらに, その 光がものや素材に照射され，ものの表面の明るさとしての光が捉え られている認識モデルである。ものや素材の表面での光が空間の中 で捉えられており, 建築空間に用いられる素材の描写と共に, 空間 の明るさが表現され，建築空間をより印象的にあらわしているとい える。内部空間と外部空間が相まって生じる光を表現することで, 室空間の雰囲気をより印象的に表現している描写などがみられた。 類型 $\mathrm{x}$ は，ものや素材の表面の明るさとしての光が捉えられている 認識モデルである。室空間の構成部材の表面に光が照射され, その 表面の明るさの特徴を表現している描写, 建築物に用いられる素材 に光が照射され, それに伴って生じる素材のもつ特有の光を表現し ている描写などがみられた。類型 xiは, 建築空間に視覚的な光の表 現ではなく, 建築物の背景や用途から感じられる光のイメージが想 起されることが多く, 空間要素が空間内での特異点となっているこ とを表現するために光に例えて象徵的に表現している描写などがみ られた。

\section{9. 形容句と作用句と認識モデルからみる光の多義性}

前章までの形容句，作用句と光の種類のコレスポンデンス分析か ら横軸に形容句から得られた性質, 縦軸に作用句から得られた性質 を認識モデルの類型を考慮した結果, 建築分野における光の多義性 として, A〜Q を導き出すことができた（図 5 )。A は, 類型 $\mathrm{i}, \mathrm{ii}$ により光源として主に太陽に関する光を捉え,「南国の日射しを受け る」注38) などの描写のように，〔場所性〕、〔季節〕，〔方位〕などで光 に時と場による限定の意味を与えることで, 太陽の光の気候環境と しての側面を強めている。Bは, 類型vi，vii， viiiにより空間の明る さを捉え,「均等な照度が確保される」注39) などの描写のように, 〔均 質〕, 〔安定・不安定〕を用いることで, その明るさが変化しやすい ことを暗示させる。その上で, 光の一定の状態に対して, [獲得 $]$, [維持］などを用いることで, 室環境に対する光の性能の確保を表 現している。C は, 類型 i, ii により主に太陽の光を光源として捉 え, 〔強弱〕，〔苛烈〕を用いることで, A と同様に太陽の光の気候環 境としての側面を強めている。しかし，これらの形容句は光が空間 に対して過剩なものであることも表現するため, [遮断], [回避]と 組み合わさることで, 劣悪な環境を生じる否定的な光を表現してい る。対してDは,「ふんだんな自然光」注 40),「暖かい光」注41) など 〔豊富〕，〔温冷感〕を用いることで，C と同様に光の量的な強さを表 現しているが，豊かさをもつ肯定的な光として捉える中で，[導入〕， 〔侵入〕と類型iii， vi， viiにより肯定的な光を空間へ導入する様子を 表現している。Eは, 類型 iv, ix, xにより, 樹木や水面など主に 自然環境に照射される光を捉えている。これに係わる自然環境とし ては山や樹木と水面が大多数を占め, 〔季節〕，〔明暗〕などと［反 射，［浸透］などを組み合わせることで，「明るい日差しが葉にはね かえる」注42), 「夏の外光が青野を輝かせる」注43) など風景としての光 を表現している。F， G は，ものや素材の表面にあらわれる光を捉え ており, 素材のもつ光沢を光源として捉える類型 $\mathrm{i}$ や他の光源によ り素材が照らされることで生じる反射した光の様子を捉える類型 iv などがあらわれた。例えば，金属であれば，その反射率の高さから 「鋭い光」注44)などの描写が多く用いられ，素材のもつ特徴が形容句 に強くあらわれる。また，木材の表面に生じる光であっても「いぶ し銀のような輝き」注45) など全く違う素材の描写を用いることで，そ の素材に固有にあらわれる光を印象的に表現するものもあらわれた。 $\mathrm{H}$ は, 類型 ii 〜 vii の認識モデルにより, 空間から空間へ移動する光 が捉えられる中で, 空間要素として《空》や《ルーバー・庇》, 《ガ ラス》など建築物の境界面に関する構成部材は光と係わりをもつこ とが多い。建築物の物理的な構成が光の量や質感を変化させ, 導入 寸る際に動きを生じさせているような表現がみられた。I, Jは，主 に作用句によって意味付けられる側面が強い描写であり, 光の動き を表現するものである。I は, [被浴]，[流出入］など本来，水の性 質である描写を光に用いており,「光を浴びる」注46), 「明かりが漏れ る」注47), などの描写により, 建築空間に光が導入, 照射される様子 をより印象的に表現している。対して J は, 擬人化された光の動き を表現しており，作用句として多様な表現があらわれた。「怪しげな 光が誘う」注 48), 「広場に巨大な光が盛り上がる」注49), 「踊る光を内 部空間に届ける」注50) などの描写により, 人に対する光の魅力を表 現するもの, 空間に対する光の演出性を表現するもの, 構成部材と 光の関係を印象的に表現するものなどがあらわれた。注59) $\mathrm{K}$ は, 〔形 


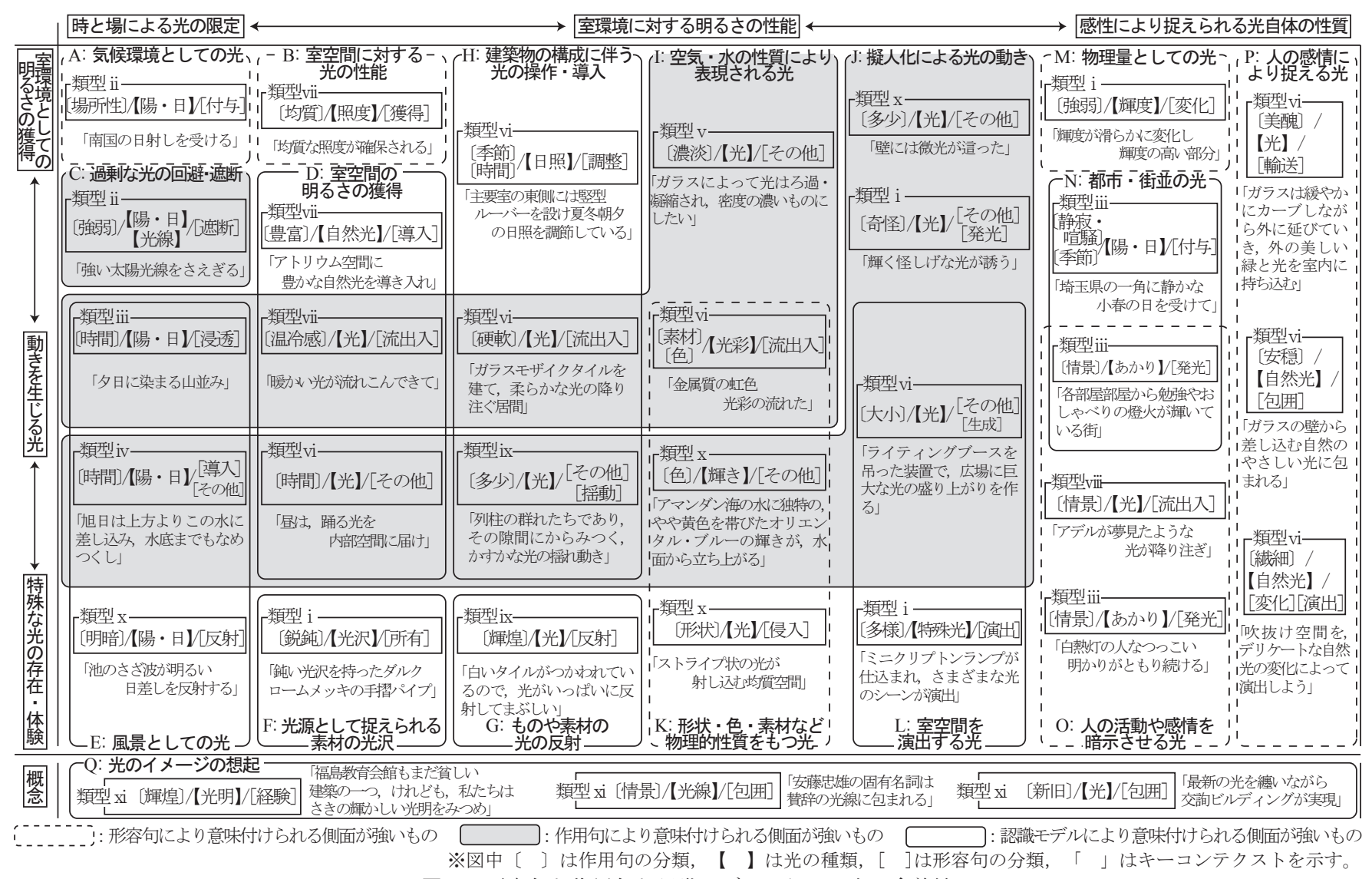

図 5 形容句と作用句と認識モデルからみる光の多義性

状〕，〔色〕，〔素材〕を用い，さらにこれらの形容句に合わせた［侵 入 ， [流出入 $]$ などの作用句を用いることで，「ストライプ状の光が 差し込む」注51) などの描写のように, 光に物質的な性質を見出すと共 に, さらに光の動的なふるまいを感じ取っている。 $\mathrm{L}$ は, 類型 $\mathrm{iii} \sim \mathrm{ix}$ の認識モデルにより，空間の明るさとしての光を捉えている。空間 要素としては人工的な光を作り出すものが光と係わりをもち，その 上で,【光】や【輝き】、【特殊光】などが，「さまざまな」注52)や「巨 大な」注53) などの描写である〔多様〕や〔大小〕などによって特徴あ るものとして表現されている。さらに作用句では, [演出], [生成], [配置］などと組み合わさることで，人為的に空間に光が生じさせら れている様子を表現している。このように, 人為的に空間に生じさ せる光を表現することによって, 室空間を演出する光を表現してい るといえる。 M は, 類型 $\mathrm{i}$ の認識モデルにより, 物理量としての光 を捉えているといえる。前述した室空間に対する光の性能の表現と 類似しており，物理量として表現された光は，それが，室空間の性 能を示寸指標として表現されている。 $\mathrm{N}$ は, 類型 iii, vi, viiilより, 都市空間の描写の中で, 主に空間の明るさとしての光を捉えている。 「小春の日」注54) などの描写のように〔季節〕や〔場所性〕を用い, 光の気候環境としての側面を捉え, 設計条件として敷地環境を説明 するものや,「柔らかい自然光」注 55) といった光の質感に関する意味 を与えることで, 敷地や都市環境の䨌囲気の特徴を明確にするもの などがあらわれた。また，〔情景〕を用いることで，「おしやべりの 燈火が輝いている街」注56) など都市空間における人に活動を暗示させ る光の表現もみられた。 $\mathrm{O}$ は，〔情景〕と組み合わさることで，人の 活動や感情を暗示させる光を表現し, 建築空間や都市に生じる光が
人の感情や活動を想起させる様子を，光に意味を付加することで表 現しているといえる。建築物や都市の背景によって様々な描写がみ られ, 多様な人の感情や活動が光に象徵されていた。Pは, [安穏], 〔美醜〕、繊細〕などを用いることで, 光が建築空間と係わることで 感じられる人の感情を光に含ませ, 「ガラスの壁から差し込む自然の やさしい光に包まれる」注577 などの描写のように，人の感情により捉 える光を表現している。 $\mathrm{Q}$ は, 類型 $\mathrm{xi}$ により, 概念としての光を捉 えており，「ミニマリズムの光」注58) などの光が建築物全体や空間の イメージとして, 建築物, 室, 樹木などに象徴されていた。

以上の 17 種の光は, 形容句, 作用句と認識モデルによってさらに 特徴付けることができ, A, B , K, M, O, P は形容句によって意味 付けられる側面が強く, C, I, J は作用句によって意味付けられる側 面が強い, さらに, D, E, F, G, H, L , N , Q は認識モデルによっ て意味付けられる側面が強いものであった。以上を踏まえると， A, $\mathrm{B}, \mathrm{K}, \mathrm{M}, \mathrm{O}, \mathrm{P}$ は, 形容句が光自体のもつ特徴を意味付ける側面 が強いために, 光自体の特徵が強く表出している表現であるといえ, それに対し C, I, J は, 作用句が光の建築空間内でのふるまいの特 徵を意味付ける側面が強いために, 光の建築空間との係わり方の特 徵が強く表出している表現であるといえる。そしてさらに，D，E， $\mathrm{F}, \mathrm{G}, \mathrm{H}, \mathrm{L}, \mathrm{N}, \mathrm{Q}$ は, 光に対して特定の空間要素の係わり方が強 く表出している表現といえる。

よって, これまで光の多義性は, 建築空間に対して, 光自体がひ とつの特徵をもつこと, 光と空間要素との係わり方がひとつの特徴 をもつこと, 光に対して特定の空間要素が担う役割が存在すること の中で見出されてきたといえる。 


\section{0．結論}

本研究では, 建築家の言語描写における光の多義性について, 形 容句，作用句々認識モデルから考察を行った。

まず，形容句は，光の描写に用いられることで，光に対する時間 や場所による限定，触覚や聴覚といった五感，光と色や形態，質感 を把握する知覚，光に対する態度や価值づけをする感情，光の善悪 を決定する判断など，実際には視覚を通して感じる光を自身の解釈 の基にどのような光の一側面に落とし込むのか，その認知過程の差 異が描写にあらわれていた。そして, 形容句と組み合わさる光の種 類のカテゴリを全体の用法として相関を考察した結果，形容句によ って描写される光は大きく，時と場による光の限定，室環境に対す る明るさの性能，感性により捉えられる光自体の性質の 3 つに大き く整理することができた。

また，作用句は，光の描写に用いられることで，光の建築空間と の係わり方を，物体として捉えられない光の物理現象，もの・流体・ 人に擬態化した動き, 操作や管理されるものなどに置き換えて描写 する。そして，作用句と組み合わさる光の種類のカテゴリを全体の 用法として相関を考察した結果，作用句によって描写される光は大 きく, 室環境としての明るさの獲得, 動きを生じる光, 特殊な光の 存在・経験の 3 つに整理することができた。

これらを踏まえて, さらに, 光の空間に対する存在の仕方として, 発光体としてそれ自体が光を発する光源としての光, 構成部材や素 材などの物理的な境界を介して空間から空間へと移動する光，空間 全体の明るさとして生じる光，ものや素材の表面の明るさとしての 光の 4 つのスケールを光の一連の流れとして, これら形容句と作用 句に加えて考察した結果，建築領域における言語描写としての光の 多義性を少なくとも 17 の類型が認められることを明らかにした。こ れらの光は，形容句によって意味付けられる側面が強く，光自体の 特徵が強く表出している表現や, 作用句によって意味付けられる側 面が強く, 光の建築空間との係わり方の特徵が強く表出している表 現, そして, 光に対して特定の空間要素の係わり方が強く表出して いる表現がみられた。

\section{謝辞}

本稿を進めるにあたって, 大井亮氏（名古屋工業大学大学院博士 前期課程）には資料，論文作成にあたり多大な御協力をいただきま した。文末ではありますが，ここに記して感謝申し上げます。

注

注 1）本稿では，光の種類，形容句，作用句，光の認識モデルをキーコンテ クストから抽出しており, これらの語の描写内容が表寸意味と照らし 合わせて結論を導出している。そのため, 考察や図中における「」内 の記述例では, 抽出元となったキーコンテクストを考察内容や図の表 現内容に合わせて, 品詞の活用の変換や文章の省略を行い例示してい るが，文法上の表現を変えてもこれによる本稿の結論に対しての影響 はないものと考える。

注 2）形容句の中には，修飾・被修飾の関係だけでなく，主語・述語の関係 および目的語に光が扱われる場合も含め，文法上の定義に拘らず，光 の性質・状態を表現する描写も研究対象として抽出している。

注 3）作用句の中には，修飾・被修飾の関係だけでなく，主語・述語の関係 および目的語に光が扱われる場合も含め，文法上の定義に拘らず，光 の動作・作用を表現する描写も研究対象として抽出している。

注 4）コレスポンデンス分析とは，集計済みのクロス集計結果を使って，行 の要素と列の要素を使い, それらの相関関係が最大になるように数量
化して, その行の要素と列の要素を多次元空間（散布図）に表現する ものである。類似度・関係性の強い要素同士は近くに，弱い要素同士 は遠くにプロットされる。ただし，相対的な位置関係であり，絶対的 なものではない。このとき，軸がクロス寸る原点付近にプロットされ る要素は比較的特徴が薄いと解釈できる。

注 5）「夏の直射日光は中へ入らないが，冬の暖い日ざしは診察室の奥ふかく 入ることになっている」, 新建築, pp.108, 1952.10

注 6）「南側のものは庇ルーバーであるが，これは夏期の日射を考慮したもの であるが，冬期でもこの種建築にはもう一段の調整を必要とする」，新 建築, pp.7, 1954.3

注 7）「南面の強い光と影がこの北側の反射光で和らげられ，光格子からは光 のアクセントがときおりさしこむ」，新建築，pp.195，1985.3

注 8）「北国では柔らかい光と透明な空気が，物と周囲に銀色の輝きを生じさ せ，物とその影，ひとつの物と他の物は，その輝きでもの柔らかくつ ながれている」, 新建築, pp.156, 1962.10

注 9）「屋根面の堅はぜと壁面の出目地も夕刻の光をとらえ，面上にもうひと つの線の構成を表出させて, 素材の重量感を軽減する役割をもたせて いる」, 新建築, pp.169, 1994.7

注 10）「奥行きのある大空間において均等で安定した照度を確保するため，2 段にわたるハイサイドライトや外壁に沿った大きなガラススクリーン を計画した」, 新建築, pp.210, 2001.5

注 11）「この託児所においては，LVL の網代耕造を圧縮材としてトンネル状の アーチを形成し，縦横の LVL 材格子の穴から室内に適度な自然光が入 る空間を考えた」，新建築，pp.123，2001.8

注 12）「ラウンジは，日中は，内外にわたる楕円の空間の一体感を強調するた めに自然光をふんだんに取り入れ，それに対してロビーは落ち着いて 雾囲気にするため明るさを抑えている」, 新建築, pp.219, 1995.7

注 13）「3つの独立したエレベーターコアをはさむ 2 ないし 3 戸の住戸は，南 面する居間・食堂と北側の庭園を俯瞰する寝室部分とで構成され，多 方向からの採光通風と独立性が確保されている」, 新建築, pp.248, 1971.5

注 14）「外部側壁面は垂直方向からの光で色彩が変化し，ホワイトペンキは水 平からの光でモノクログラディションを映している」, 新建築, pp.213, 1980.2

注 15）「4 階は多目的ホールで, 床に埋め込まれたアッパーライトは 4 色に変 化し，客席を鮮やかに照らし出す」，新建築，pp.250，1990.1

注 16）「この夢幻的な階段を登ってゆくと，おびただしいピンクの光線で埋ま ったチューブの中を泳いでいるようだ」，新建築，pp.148，1968.3

注 17）「街は白い太陽光に包まれていつも穏やかな表情をみせている」，新建 築, pp.332, 1990.7

注 18）「質感においても，金属的な光沢をもったアルミニウムパネルでおおお れ，冷たく，とりつきにくい, 新建築，pp.186, 1978.9

注 19）「木曽檜は美しく老いる.やがて年月が経つにつれ，いぶし銀のような 輝きを増していくことであろう」, 新建築，pp.268，1992.3

注 20）「しかしイランモスクのは内部空間全面に張り巡らされた壮麗なもので あり, 凹凸がきめ細かく繰り返される幾何学模様の浮き彫りに沿って 鏡モザイクが貼られているから，これに差し込む光はまさにキラキラ と輝くダイヤモンドのごとく目を見張る乱反射なのである」, 新建築, pp. $167,1995.5$

注 21）「シャッター閉鎖時には，室内にやわらかな自然光を入れ，解放時はオ 一バーハングしたシャッターが庇となり室内と庭の間に中間的領域を つくる」, 新建築, pp. $88,2003.1$

注 22）「2 階の子供部屋の前には瓦屋根に囲まれた暖かい静かな日だまりを抱 き込んでみたかった」, 新建築, pp.175, 1982.2

注 23）「大自然の中に超個性的ともいうべき自由さで，冷たい光芒を放ってい るその大彫刻の姿を見て，このときほど彫刻家をうらやましく思った ことはない, 新建築, pp.184, 1977.1

注 24）「この「泡」の頂部はホールの天空を貫き，柔らかな光と天空を「泡」 の表面に沿って内部へ送り込んでいる」, 新建築, pp.147, 1998.7

注 25）「夜には, その屋根のズレからロックデッキとビームのテクスチャーに 反響した暖かい光がこぼれ出し，そこで生まれるであろうホットでビ 一トを予感させるのである」，新建築，pp.247，1992.12

注 26）「北西に長く配置したガレリアのような空間は，自然の光の変化を全身 に受け止め, 日没には真っ赤な夕日が館内を染め, やがてインディゴ の闇に覆われていく」, 新建築, pp.129, 2004.2 
注 27）「駅のプラットホームに立ち, これから向かう広島方向に視線を向ける と，朝日を浴びた外壁が白く眩しい」，新建築，pp.159, 2002.9

注 28）「ある会社にとって生活的価值を失った歷史的遺産がなぜ今日に生き続 ける必要があるのかと, 一種の因果関係に似たものを思いながらも, 自分の頭の中には漠然と杉並木の木肌の色や車の橴滞をよそ目にどっ しりと根を下している杉の土着の力強さ, そして光と霞みに包夕込ま れた幻想的空間や日光連山を背景に, 北関東平野の”どんづまり”と して，田畑に囲まれた敷地の現実が交差する中でスケッチが進められ た」, 新建築, pp.240, 1977.9

注 29）「昼間，太陽の光と陰で美しくきらめき，夕暮時，電灯が灯され明るく 輝く光の樹から音楽が流れてくる」, 新建築, pp.227, 1970.5

注 30）「トップライトに光を当て外構照明柱と含めて光の色温度を調整して, 暖かな光のアンサンブルをつくり出した」, 新建築, pp.173, 1999.2

注 31）「空間の形態と材料の質を高めるような光の分布を壁は用意する」，新 建築, pp.10, 1957.2

注 32）「このシリンダーの濃青の色光パターンはすべて宇宙の大海を表し，同 時にシリンダーが置かれた大海という地名のイメージを重ねている」, 新建築, pp.230, 1975.6

注 33）「道行く人は, パースペクティブな奥行きの中に, 北側の澄んだ, 静 穏な光と, さわやかな風の流れを体感することができる」, 新建築, pp.292, 1992.8

注 34）「駅のプラットホームに立ち，これから向から広島方向に視線を向ける と，朝日を浴びた外壁が白く眩しい」，新建築，pp.159, 2002.9

注 35）「屋根面には最小限のダウンライトを点灯し，周囲の建築物の廊下・バ ルコニーから洩れる光と，植え込みの中に見え隠れする足下照明によ って都市公園的な明るさを保つ, という計画が行われている」, 新建 築, pp.194, 1979.7

注 36）「又其の軽量であることを考慮する必要がある館内採光に関しては，体 育館として使用される場合も考慮し, トップライト及側高空によって 充分なる採光が計画されている」, 新建築, pp.135, 1950.5

注 37）「平面計画は各室とも南面し，冬期の陽光を受けることを基本とし，ま た保育室の中間には春を待つ間の室内砂場を設けている」, 新建築, pp.226, 1977.4

注 38）「側面（隣地側）を開放して南国の強い日射しを直接受け入れるので はなく, やわらかな日射しに変えたいということと, 近隣からプライ バシーを守るという意図から，枡組のルーバーで囲む方法を採ってみ た」，新建築，pp.260，1986.12

注 39）「奥行きのある大空間において均等で安定した照度を確保するため， 2 段にわたるハイサイドライトや外壁に沿った大きなガラススクリーン を計画した」, 新建築, pp.210, 2001.5

注 40）「使用を特定されないままにしばらく放り出されていた幅 $12.0 \mathrm{~m}$, 奥 行き $6.4 \mathrm{~m}$, 高さ $3.15 \mathrm{~m}$ のこの単純な箱には庭と外部吹き抜けが併設 し, それらからは自然光がふんだんに侵入してくる」, 新建築, pp.165, 2001.1

注 41）「そこで，「照明プランター」の足元から暖かい光を放射状に発するこ とで, 街路空間を演出した」, 新建築, pp.226, 1994.3

注 42）「住棟と住棟の間には濃い緑が茂り，葉がキラキラと明るい日差しをは 数返している」，新建築，pp.174，1979.12

注 43）「松林越しに, 冬は枯野, 夏は青野が外光に輝く」, 新建築, pp. 58 , 1960.2

注 44）「しかしそれにもまして，8月の太陽に受けて鋭く光るアルミの感触に 惹かれたというほうが真実だろう」, 新建築, pp.228, 1971.10

注 45）「木曽檜は美しく老いる。やがて年月が経つにつれ，いぶし銀のような 輝きを増していくことであろう」, 新建築, pp.268, 1992.3

注 46）「手を合わせて，あたかも朝の光を浴びるように東面一杯に迎え，侍立 しながら，頂部だけをあかあかと燃え上がらせて，雲の中に看えてい る」, 新建築, pp.239, 1989.1

注 47）「屋根に突き出る階段室と天空は, 遠望からのシンボリックな形態とし て自然風景に対峙する。夜には明かりが漏れ，湖に建つ灯台を思わせ る風景が創出される」, 新建築, pp.133, 2000.7

注 48）「さて，夜毎憶面もなく輝く怪しげな光に誘われてか否か，その後，著 しく若者たちの耳目を集め, この度ファッション教育部門を増設す る運びとなり, そのための学舎を建設することになった」, 新建築, pp. $98, \quad 2002.5$

注 49）「トロリーに特殊照明用のライティングブースを吊った装置で，カラー
テレビ撮影の可能な舞台鉛直面 2,0001x の照度を出し，広場に巨大な 光の盛り上がりを作る」, 新建築, pp.178, 1970.5

注 50）「二つの空は,”アーバンウィンドウ (都市の空)”としてアーバニティ を高め, 建物と都市とのコミュニケーションを促し，昼は，躍る光を 内部空間に届け, 内なる自然の風景をつくりだしてくれる」, 新建築, pp.290, 1993.6

注 51）「ストライプ状の光が差し込む均質空間の水平な拡がりの中で，スペー スディバイダーとしての透明なガラスが 7 つ空間をつくっている」, 新建築，pp.189，1984.6

注 52）「人工の大地の上につくられた人工のランドスケープと街並み，それ らは金属の被膜を身にまとい，太陽の光によってさまざまな輝きを放 つ」, 新建築, pp.226, 1989.12

注 53）「トロリーに特殊照明用のライティングブースを吊った装置で，カラー テレビ撮影の可能な舞台鈆直面 $2,0001 \mathrm{x}$ の照度を出し，広場に巨大な 光の盛り上がりを作る」, 新建築, pp.178, 1970.5

注 54）「今は町村合併を行い，物わかりの良い親父のような市長を中心に模範 的な行政の市として, 平和と活気の中に埼玉県の一角に静かな小春の 日を受けて展開している」, 新建築, pp.37, 1958.4

注 55）「シャッター閉鎖時には，室内にやわらかな自然光を入れ，解放時は才 一バーハングしたシャッターが庇となり室内と庭の間に中間的領域を つる」, 新建築, pp.88, 2003.1

注 56）「夜になっても各部屋部屋から勉級やおしやべりの燈火が輝いている 街, 静かで華やかでかつそれでいて高密度な容積構成, といった方 向」, 新建築, pp.154, 1970.6

注 57）「旅客ターミナルに足を踏み入れた利用客は，頭上の半透明な膜材の天 井とまわりのガラスの壁から差し込む自然のやさしい光に包まれる」, 新建築, pp.262, 1994.4

注 58）「吹き抜けに孟宗竹を植えることで，バスタブに張られた水と共に，ミ ニマリズムの光と風と水と緑の溢れるサニタリースペースをつくっ た」, 新建築, pp.171, 2002.4

注 59）本稿の分析手法において, 注 24）, 注 25）, 注 26）, 注 47）, 注 50）の 記述における考察結果は，参考文献 1）～3）に記した成瀬徳行の既往 論文（一文を基準として，述語動詞の性質や態を元に分析を進める研 究）と類似の所見を得られた。

\section{参考文献}

1）成瀬徳行 : 建築家の言説における受動態の研究 SD REVIEW に見られる 建築家のレトリック (その 1 ), 日本建築学会計画系論文集, 第 538 号, pp.277-284, 2000.12

2) 成瀬徳行 : 建築家の言説における自動詞の研究一SD REVIEW に見られる 建築家のレトリック (その 2)，日本建築学会計画系論文集，第 553 号, pp.325-332, 2002.3

3）成瀬徳行：建築家の言説における補助動詞の研究 SD REVIEW に見られ る建築家のレトリック (その 3 ), 日本建築学会計画系論文集, 第 577 号, pp.217-224, 2004.3

4）塩崎太伸，奥山信一：現代日本の建築家の設計論にみられる対概念 対照 性を利用した建築的思考の文脈と形式に関寸る研究，日本建築学会計画系 論文集，第 610 号, pp.79-86, 2006.12

5）山内一晃, 吉田勝行 : 建築形態構成における「概念語」と「形態語」の 関係性について，日本建築学会計画系論文集，第 559 号，pp.137-144， 2002.9

6）小泉隆，桶師徳行，鈴木信宏 : 自然光の構成とその知覚状態からみた建築 空間におけるまとまりと方向性を与える自然光タイプ，日本建築学会計画 系論文集，第482 号, pp.95-103，1996.4

7）熊澤貴之, 中村芳樹：光環境の認識における個人差 室内光環境の認識 に及ぼす体験の影響（その 1)，日本建築学会計画系論文集，第 534 号， pp.77-82, 2000.8

8）吉澤望, 堀口裕美, 平手小太郎, 武田仁 : 現象学的見地からの光の分類 フェノメナルな光の工学的条件に関する研究 (その 1 ), 日本建築学会計 画系論文集, 第 584 号, pp.35-42, 2004.10

9) 新建築社 : 新建築, 1945.1-2008.12

（2012年 2 月 10 日原稿受理， 2012年 6 月 29 日採用決定） 